Mutation and haplotype analysis of the CFTR gene in atypically mild cystic fibrosis patients from Northern Ireland

EDITOR-Although cystic fibrosis (CF) is a monogenic disorder of autosomal recessive inheritance, it displays a diverse clinical phenotype. Over 1000 molecular lesions in the cystic fibrosis transmembrane conductance regulator (CFTR) gene together with the action of modifying genes can result in the variable expression of $\mathrm{CF}^{1{ }^{2}}$

Classical CF causes dysfunction of the lung, sweat glands, testis, ovary, intestine, and pancreas. ${ }^{3}$ However, there is considerable variation in measurements of the onset age, presence of pancreatic insufficiency, sweat electrolyte levels, and progression of lung disease. Particularly mild manifestations of cystic fibrosis are conveniently grouped as "atypical CF" and result from a different CFTR mutation spectrum from classical CF patients. ${ }^{4-8}$ Recognition of the wide range of disease presentation in CF is important for appropriate treatment and effective counselling of those at risk. The repertoire of other disorders associated with CFTR variants include various respiratory afflictions such as asthma, ${ }^{9}$ chronic bronchitis, disseminated bronchiectasis, ${ }^{6}{ }^{10}$ allergic bronchopulmonary aspergillosis, ${ }^{11}$ nasal polyposis, ${ }^{12}$ chronic pancreatitis, ${ }^{13}$ and certain forms of male infertility characterised as congenital absence of the vas deferens (CAVD) and obstructive azoospermia. ${ }^{8}{ }^{14}$

This report details the CFTR variants, characterised by fluorescent sequencing after screening the entire coding and surrounding intronic sequences by denaturing gradient gel electrophoresis (DGGE), in a panel of 31 unrelated atypical CF patients from Northern Ireland. The frequencies of these variants in the normal population was also examined. Automated detection of fluorescently labelled multiplex PCR fragments was used to type three intragenic CFTR dinucleotide repeats for assigning microsatellite haplotypes to the atypical CF alleles. ${ }^{15}$ The genotypes for a functionally important polythymidine branch/acceptor site of intron 8 in the CFTR gene $(\mathrm{Tn}=\mathrm{IVS} 8-6(\mathrm{~T}) \mathrm{n})^{16}$ were also typed for our CF, atypical $\mathrm{CF}$, and normal chromosomes.

The affected subjects from Northern Ireland were diagnosed during neonatal CF screening by two increased levels of immunoreactive trypsin from Guthrie card samples, followed by two sweat tests at one week intervals. ${ }^{17}$ Older patients (those currently over 14 years) were diagnosed by sweat testing after referral on clinical suspicion. Diagnosis of "classical" CF is generally based on a pathological sweat test, a CFTR mutation on each CF allele, and typical clinical symptoms of gastrointestinal and pulmonary disease. ${ }^{3}$ Diagnostic problems arise when one or more of the above criteria are not fulfilled. For example, Highsmith et $a l^{18}$ reported CF gene mutations in patients with normal sweat chloride concentrations. The highest sweat electrolyte results for the atypical CF group were in the diagnostic range for $\mathrm{CF}$ (table 1), although they tended to provide borderline results which required repeating before diagnosis was made. The overall clinical course is much milder than for our CF patients, as shown by slower decline on chest $x$ ray appearances, Shwachman scores, deviation of height and weight below the mean, and decline in pulmonary function. They did not present with meconium ileus and only a few have had Pseudomonas aeruginosa infections (table 1). Only about half of the patients receive pancreatic

Table 1 The CFTR genotypes and clinical details for a panel of 31 atypical CF patients from Northern Ireland

\begin{tabular}{|c|c|c|c|c|c|c|c|c|}
\hline Patient & CFTR mutations & Tn genotype $e^{\star}$ & Sex/age $(y)$ & $\begin{array}{l}\text { Sweat } \\
\text { chloridet }\end{array}$ & $\begin{array}{l}\text { Bacterial } \\
\text { infection } \neq\end{array}$ & $\begin{array}{l}\text { Pancreatic } \\
\text { status\} }\end{array}$ & $\begin{array}{l}\text { Shwachman } \\
\text { score }^{3}\end{array}$ & $F E V_{1} \%$ ฯ \\
\hline 1 & $\Delta \mathrm{F} 508 / \mathrm{R} 75 \mathrm{Q}+5 \mathrm{~T}$ & $9 /(11) 5$ & $\mathrm{M} / 32$ & 93 & PA & PI & $18 / 25$ & 80 \\
\hline 2 & $\Delta \mathrm{F} 508 / \mathrm{R} 117 \mathrm{H}+5 \mathrm{~T}$ & $9 /(12) 5$ & $\mathrm{M} / 9$ & 74 & $\mathrm{HI}$ & PI & $21 / 25$ & 90 \\
\hline 3 & $\Delta \mathrm{F} 508 / \mathrm{R} 75 \mathrm{Q}$ & $9 / 7$ & $F / 32$ & 65 & $\mathrm{n}$ & PS & $23 / 25$ & 92 \\
\hline 4 & $\Delta \mathrm{F} 508 / 5 \mathrm{~T}$ & $9 /(11) 5$ & $\mathrm{M} / 7$ & 83 & $\mathrm{n}$ & PS & $24 / 25$ & - \\
\hline 5 & $\Delta \mathrm{F} 508 / \mathrm{U}$ & $9 / 7$ & $F / 23$ & 81 & $\mathrm{HI}$ & PS & $19 / 25$ & 87 \\
\hline 6 & $\Delta \mathrm{F} 508 / \mathrm{U}$ & $9 / 7$ & $\mathrm{~F} / 11$ & 63 & $\mathrm{n}$ & PS & $23 / 25$ & 103 \\
\hline 7 & $\Delta \mathrm{F} 508 / \mathrm{U}$ & $9 / 7$ & $F / 24$ & 103 & PA & PI & $13 / 25$ & 66 \\
\hline 8 & $\Delta \mathrm{F} 508 / \mathrm{U}$ & $9 / 7$ & $\mathrm{~F} / 13$ & 83 & $\mathrm{n}$ & PS & $18 / 25$ & 81 \\
\hline 9 & $\mathrm{R} 75 \mathrm{Q} / \mathrm{U}$ & $7 / 7$ & $\mathrm{~F} / 20$ & 117 & $\mathrm{HI}$ & PI & $20 / 25$ & 88 \\
\hline 10 & $\mathrm{R} 75 \mathrm{Q} / \mathrm{U}$ & $7 / 7$ & $\mathrm{M} / 6$ & 84 & $\mathrm{HI}$ & PS & $19 / 25$ & - \\
\hline 11 & $\mathrm{R} 75 \mathrm{Q} / \mathrm{U}$ & $7 / 7$ & $\mathrm{M} / 33$ & 96 & $\mathrm{n}$ & PI & $21 / 25$ & 86 \\
\hline 12 & $\mathrm{~S} 1235 \mathrm{R} / \mathrm{U}$ & $\mathrm{x} / \mathrm{x}$ & $\mathrm{F} / 18$ & 69 & $\mathrm{HI}$ & PI & $24 / 25$ & 90 \\
\hline 13 & $\mathrm{~S} 1235 \mathrm{R} / \mathrm{U}$ & 7 or $9 / 7$ or 9 & $\mathrm{M} / 22$ & 76 & $\mathrm{n}$ & PI & $20 / 25$ & 119 \\
\hline 14 & $\mathrm{R} 117 \mathrm{H}+5 \mathrm{~T} / \mathrm{U}$ & (12) $5 / 7$ & $\mathrm{M} / 17$ & 91 & PA & PI & $20 / 25$ & 77 \\
\hline 15 & $\mathrm{R} 297 \mathrm{Q}+5 \mathrm{~T} / \mathrm{U}$ & (11) $5 / 7$ & $\mathrm{~F} / 14$ & 62 & $\mathrm{n}$ & PI & - & - \\
\hline 16 & $5 \mathrm{~T} / \mathrm{U}$ & (11) $5 / 7$ & $\mathrm{M} / 13$ & 79 & $\mathrm{n}$ & PI & $21 / 25$ & 75 \\
\hline 17 & $5 \mathrm{~T} / \mathrm{U}$ & (12) $5 / 7$ & $\mathrm{~F} / 20$ & 74 & $\mathrm{n}$ & PS & $22 / 25$ & 100 \\
\hline 18 & $5 \mathrm{~T} / \mathrm{U}$ & (11) $5 / 7$ & $\mathrm{M} / 28$ & 55 & $\mathrm{n}$ & PI & $19 / 25$ & 68 \\
\hline 19 & $\mathrm{U} / \mathrm{U}$ & $7 / 7$ & $\mathrm{M} / 8$ & 58 & $\mathrm{HI}$ & PS & $19 / 25$ & 94 \\
\hline 20 & $\mathrm{U} / \mathrm{U}$ & $7 / 9$ & $M / 26$ & 74 & $\mathrm{n}$ & PS & $23 / 25$ & 106 \\
\hline 21 & $\mathrm{U} / \mathrm{U}$ & $9 / 7$ & $\mathrm{M} / 8$ & 55 & $\mathrm{HI}$ & PS & $22 / 25$ & - \\
\hline 22 & $\mathrm{U} / \mathrm{U}$ & $7 / 7$ & $\mathrm{M} / 8$ & 77 & $\mathrm{n}$ & PS & $21 / 25$ & - \\
\hline 23 & $\mathrm{U} / \mathrm{U}$ & $7 / 9$ & $\mathrm{M} / 12$ & 58 & $\mathrm{HI}$ & PI & $21 / 25$ & 92 \\
\hline 24 & $\mathrm{U} / \mathrm{U}$ & $7 / 7$ & $\mathrm{M} / 12$ & 61 & $\mathrm{n}$ & PI & $19 / 25$ & 91 \\
\hline 25 & $\mathrm{U} / \mathrm{U}$ & $7 / 7$ & $\mathrm{M} / 21$ & 72 & $\mathrm{n}$ & PS & $22 / 25$ & 96 \\
\hline 26 & $\mathrm{U} / \mathrm{U}$ & $7 / 7$ & $\mathrm{~F} / 7$ & 89 & $\mathrm{n}$ & PI & $21 / 25$ & 87 \\
\hline 27 & $\mathrm{U} / \mathrm{U}$ & $7 / 7$ & $\mathrm{M} / 8$ & 65 & $\mathrm{n}$ & PS & $23 / 25$ & - \\
\hline 28 & $\mathrm{U} / \mathrm{U}$ & $7 / 7$ & $\mathrm{~F} / 15$ & 78 & $\mathrm{HI}$ & PI & $20 / 25$ & 76 \\
\hline 29 & $\mathrm{U} / \mathrm{U}$ & $7 / 7$ & $\mathrm{~F} / 28$ & 111 & PA & PI & $16 / 25$ & 72 \\
\hline 30 & $\mathrm{U} / \mathrm{U}$ & $9 / 7$ & $\mathrm{M} / 10$ & 84 & $\mathrm{n}$ & PS & $20 / 25$ & 81 \\
\hline 31 & $\mathrm{U} / \mathrm{U}$ & $9 / 7$ & $\mathrm{M} / 9$ & 66 & $\mathrm{n}$ & PI & $22 / 25$ & 93 \\
\hline
\end{tabular}

* The number of TG repeats (IVS8GT) upstream of the Tn tract is given in brackets only before a T5 score as their number can modulate alternative splicing only when this is activated by the T5 allele. ${ }^{16} \mathrm{U}=$ unknown (no mutation detected), $\mathrm{M}=$ male, $\mathrm{F}=$ female, $\mathrm{x}=$ uncharacterised.

†High sweat levels, diagnostic of CF, are those above $70 \mathrm{mmol} / \mathrm{l} \mathrm{chloride,} \mathrm{borderline} \mathrm{levels} \mathrm{are} 40-70 \mathrm{mmol} / 1$, and normal levels are below $40 \mathrm{mmol} / 1 .{ }^{17} \mathrm{In}$ the atypical cohort, 20 patients have high sweat levels and 11 have borderline values.

$\ddagger \mathrm{HI}=$ Haemophilus influenza, $\mathrm{PA}=$ Pseudomonas aeruginos $a, \mathrm{n}=$ no bacterial growth detected

$\$ \mathrm{PI}=$ pancreatic insufficient, $\mathrm{PS}=$ pancreatic sufficient.

$\uparrow \mathrm{FEV}_{1} / \mathrm{FVC} \%$ = forced expiratory volume in one second / forced vital capacity, as a percentage. $-=$ no value available. 
enzyme supplements (Aileen Redmond, Royal Victoria Hospital, Belfast, personal communication).

DNA samples from the atypical CF patients were analysed by DGGE and variants characterised by fluorescent sequencing as for our CF cohort. ${ }^{19}$ This screening procedure enabled detection of all 80 control CFTR variants spread through all the exons.

The six CFTR variants and their associated Tn genotypes found in the atypical CF samples are shown in table 1 . They were present on 22 of the 62 CFTR alleles examined (35\%). Only four patients (Nos 1-4 in table 1) had CFTR defects detected on both chromosomes. Of the 31 subjects tested 18 had at least one CFTR defect characterised (58\%), which is significantly different from both normal and cystic fibrosis populations from Northern Ireland (the 30 CFTR mutations found in our CF population account for $94 \%$ of the CF alleles in Northern Ireland ${ }^{19}$ ). Twelve of the chromosomes carried one of three pathogenic mutations typically found in CF: $\Delta$ F508 (eight alleles), R117H (two), and S1235R (two). The latter defect is also associated with disseminated bronchiectasis. ${ }^{6}$ Three of the amino acid changes detected, R75Q, R297Q, and S1235R, were not observed in CF patients from Northern Ireland. ${ }^{19}$

A $5 \mathrm{~T}$ tract in the splice acceptor site of intron $8(\mathrm{Tn})$, which greatly decreases the amount of available full length CFTR mRNA, ${ }^{16}{ }^{20}{ }^{21}$ was typed from eight alleles. There is a wide clinical variation, from no disease to CAVD, ${ }^{22-25}$ chronic idiopathic pancreatitis, ${ }^{26}$ bronchiectasis, aspergillosis, and moderate $\mathrm{CF}^{6}{ }^{67}$ in association with this $\mathrm{Tn}$ allele that depends on the differences in levels of normal CFTR mRNA. The T5 allele effect on exon 9 skipping has been shown to increase the phenotypic severity of the $\mathrm{R} 117 \mathrm{H}$ mutation ( $\mathrm{R} 117 \mathrm{H}$ occurs on two chromosomal backgrounds, one associated with $\mathrm{T} 5$ and the other with T7) ${ }^{28}$ The frequency of the T5 allele is $12.9 \%$ in the atypical cohort and has been estimated to be some $5 \%$ in the general population. ${ }^{14}{ }^{22}$ After typing the Tn genotype in 200 normal chromosomes from Northern Ireland in this study, T5 was found to occur at a frequency of $7.1 \%$.

A substitution of arginine for glutamine at codon 75 in exon 3 was found on five chromosomes. This R75Q variant is not thought to cause multiorgan $\mathrm{CF}$ but has been found to be associated, like R117H, S1235R, and T5, with atypical CF manifestations, such as CAVD ${ }^{1422}{ }^{29}$ and bronchiectasis. ${ }^{6}$ This amino acid variant was also found in two out of 200 normal alleles but was not detected on 412 CF chromosomes. Thus, the R75Q allele is significantly more frequent in our group of atypical CF patients than in the general population ( $p=0.01$, Fisher's exact text). This observation suggests an association of the R75Q substitution with mild CF symptoms, as proposed by Zielenski and Tsui. ${ }^{30}$

Another Arg to Gln change, in codon 297 of exon 7, was previously reported as the CF mutation R297Q. ${ }^{31}$ The female sibs (aged 14 and 17) carrying this variant are now classified in the atypical group as they present with a quite mild CF phenotype (NB, only one of the R297Q alleles is counted in the cohort). R297Q was found in cis with T5 which would probably augment any deleterious effect of the amino acid change. Previously, R297Q was also reported in two healthy French sibs who both carry CF mutations on their other chromosomes. ${ }^{32}$ However, in this case the mutation occurs on a different haplotype associated with T7. Other evidence that R297Q may contribute to disease, in conjunction with a second site variation like T5, is that no further mutations were found after DGGE screening of the entire CFTR coding and flanking regions. R297Q was not detected in $206 \mathrm{CF}$ or 100 normal subjects after DGGE analysis. Interestingly, the ovine equivalent of this variant was reported as the first putative CF mutation to be detected in another species. ${ }^{33}$

Three intragenic CFTR microsatellites, IVS8CA, IVS17bTA, and IVS17bCA, were also typed for the atypical CF cohort. These haplotypes plus the Tn scores (table 2) help to postulate whether chromosomal background would modulate the effect of variants that are found in both $\mathrm{CF}$ and atypical CF. Microsatellite haplotypes associated with $\Delta \mathrm{F} 508, \mathrm{R} 117 \mathrm{H}$, and $\mathrm{S} 1235 \mathrm{R}$ are equivalent, and thus genetic background is probably similar to those obtained from $\mathrm{CF}$ patients with these mutations in Ireland and Britain. ${ }^{15} 34$

The R75Q and T5 defects were associated with several haplotypes and so would appear to be carried on different genetic backgrounds that might regulate their severity. R75Q was associated with two main haplotype backgrounds; $16-$ T7-31 or 46-13 and 17-T5-07-17. In addition to $\mathrm{R} 117 \mathrm{H}$ (the two $\mathrm{R} 117 \mathrm{H}$ alleles occur on the more pathogenic T5 background), T5 occurs in cis with both R75Q and R297Q respectively. Examination of the Tn genotypes for the 30 mutations in our independent CF cohort showed that only $\mathrm{R} 117 \mathrm{H}$ was associated with $\mathrm{T} 5$ (12 out of the $16 \mathrm{R} 117 \mathrm{H} \mathrm{CF}$ alleles). All the other CF mutations were associated with $\mathrm{T} 7$ or $\mathrm{T} 9$. There were 23 different haplotypes typed from the 40 uncharacterised atypical CF alleles, which suggests that there could be

Table 2 Haplotypes defined for 62 atypical CF alleles and their associated CFTR variants

\begin{tabular}{|c|c|c|c|c|c|}
\hline Mutation & No of alleles & Atypical CF frequency ${ }^{\star}(\%)$ & CF frequencyt (\%) & Normal frequency $\neq(\%)$ & Haplotypes $8 C A-T n-17 b T A-17 b C A$ \\
\hline$\overline{\Delta \mathrm{F} 508}$ & 8 & 12.9 & 68 & 2 & $\begin{array}{l}23-9-31-13(4) \\
23-9-32-13(2) \\
21-9-31-13(1) \\
17-9-31-13(1)\end{array}$ \\
\hline $5 \mathrm{~T}$ & 8 & 12.9 & 3.4 & 7.1 & $\begin{array}{l}17-5-07-17(3) \\
16-5-30-13(2) \\
16-5-07-17(2) \\
16-5-29-13(1)\end{array}$ \\
\hline R75Q & 5 & 8.1 & 0 & 1 & $\begin{array}{l}16-7-46-13(3) \\
16-7-31-13(1) \\
17-5-07-17(1)\end{array}$ \\
\hline $\mathrm{R} 117 \mathrm{H}$ & 2 & 3.2 & 4.1 & 1 & $16-5-30-13(2)$ \\
\hline S1235R & 2 & 3.2 & 0 & 0 & $17-7 / 9-31-13(2)$ \\
\hline R297Q & 1 & 1.6 & 0 & 0 & $17-5-07-17(1)$ \\
\hline Not known & 40 & 64.5 & 5.6 & - & $\begin{array}{l}16-7-30-13(7) \\
16-7-07-17(5) \\
16-7-32-13(5) \\
16-7-44-13(2) \\
17-7-07-17(2)\end{array}$ \\
\hline
\end{tabular}

^Frequency of the variant in the panel of 62 atypical CF chromosomes.

tFrequency of the variant in 412 chromosomes from 206 Northern Irish CF patients.

$\ddagger$ Frequency of the variant in 200 normal chromosomes from Northern Ireland.

$\S$ The figures in brackets after each haplotype denote the number of atypical alleles found with that particular haplotype. 
many other variants still to be found in the non-coding region of the CFTR gene. Recent reports suggest that some cases of atypical CF also could result from other genetic or environmental factors. ${ }^{2}{ }^{35}$

The CFTR gene has been shown to be a predisposing factor for the development of various atypical manifestations of CF. Examination of the entire coding and flanking sequences of the CFTR gene by denaturing gradient gel electrophoresis was undertaken to screen for mutations in 31 patients who express a markedly mild form of CF. They have borderline or increased sweat electrolyte levels with pulmonary dysfunction but no substantial bacterial colonisation. Three intragenic CFTR microsatellites and a Tn tract, whose T5 allelic variant causes aberrant splicing and is strongly associated with atypical CF, were typed to construct haplotypes for the disease alleles. There were six variants (including T5) characterised on 22 of the 62 alleles tested (35\%), though only 12 of these chromosomes harboured mutations commonly found in CF. While only four patients were found to be compound heterozygotes for CFTR defects, 18 (58\%) had at least one mutant CFTR allele. The CFTR genotypes for the atypical cohort are markedly different from both normal and cystic fibrosis populations from Northern Ireland.

The apparatus and optimisation of DGGE for analysis of the CFTR gene is described by Hughes et al. ${ }^{19}$ Briefly, samples were loaded in a $6 \%$ polyacrylamide gel with a linearly increasing concentration of denaturing gradient from $0 \%$ to $80 \%$ denaturant $(100 \%$ denaturant: $6 \mathrm{~mol} / 1$ urea, $40 \%$ formamide $\mathrm{v} / \mathrm{v}$ ) and analysed on a modified Biorad Protean 11 vertical electrophoresis system at a constant temperature of $60^{\circ} \mathrm{C}$. Fragments displaying altered gel mobilities were visualised by ultraviolet light after ethidium bromide staining. The corresponding PCR products were sequenced in both directions with fluorescent dyedeoxy chain terminator nucleotides on an Perkin Elmer ABI 373A sequencer. For each DGGE amplicon, control samples carrying known mutations were analysed under the same conditions and in parallel with the uncharacterised samples.

IVS8CA, IVS17bTA, and IVS17bCA were amplified by fluorescent multiplex PCR. ${ }^{15}{ }^{34}$ The reverse primers were $5^{\prime}$ end labelled with fluorescent phosphoramidites (Perkin Elmer). Samples were loaded onto $6 \%$ polyacrylamide gels (Sequagel, National Diagnostics) and analysed on a Perkin Elmer ABI 373A DNA sequencer. Markers of known size, labelled with a different phosphoramidite, were run with the samples to determine allele sizes using the Genescan 672 software according to the manufacturer's instructions. IVS8GT and IVS8-6(T)n were typed by a combination of SSCP, restriction digests, and direct sequencing as described by Dörk et al. . $^{36}$

We wish to thank the Cystic Fibrosis Research Trust for providing DH with a short term postdoctoral travelling fellowship to the medical school in Hanover (grant No UK02). We thank Aileen Redmond, Royal Victoria Hospital, Belfast, for the clinical data on the atypical CF patients. We warmly thank all our patients for always being eager to help us in our research.

\section{DAVID HUGHES*} THILO DÖRK† MANFRED STUHRMANN† COLIN GRAHAM $\ddagger$

*The Sanger Centre, Wellcome Trust Genome Campus, Hinxton, Cambs CB10 1SA, UK

†Department of Human Genetics, Medizinische Hochschule Hannover, D-30623 Hanover, Germany

$\ddagger$ Department of Medical Genetics, Belfast City Hospital, Belfast BT9 $7 A B$, Northern Ireland

Correspondence to: Dr Hughes, hughes@iarc.fr

1 The Cystic Fibrosis Genetic Analysis Consortium (http://

2 Zielenski J, Corey M, Rozmahel R, Markiewicz D, Aznarez I, Casals T, Larriba S, Mercier B, Cutting GR, Krebsova A, Macek M Jr, Langfelderriba S, Mercier B, Cutting GR, Krebsova A, Macek M Jr, Langfelder-
Scwind E, Marshall BC, DeCelie-Germana J, Claustres M, Palacio A, Bal Scwind E, Marshall BC, DeCelie-Germana J, Claustres M, Palacio A, Bal
J, Nowakowska A, Ferec C, Estivill X, Durie P, Tsui LC. Detection of a cystic fibrosis modifier locus for meconium ileus on human chromosome 19q13. Nat Genet 1999;22:128-9.

3 Welsh MJ, Tsui LC, Boat TF, Beaudet AL. Cystic fibrosis. In: Scriver CR, Beaudet AL, Sly WS, Valle D, eds. The metabolic and molecular basis of inherited disease. New York: McGraw Hill, 1995:3799-876.

4 Gervais R, Dumur V, Rigot JM, Lafitte JJ, Roussel P, Claustres M, Demaille $\mathrm{J}$. High frequency of the R117H cystic fibrosis mutation in patients with congenital absence of the vas deferens. $N$ Engl f Med 1993;328:446-7.

5 Gervais R, Lafitte JJ, Dumur V, Kesteloot M, Lalau G, Houdret N, Roussel P. Sweat chloride and delta F508 mutation in chronic bronchitis or bronchiectasis. Lancet 1993;342:997.

6 Pignatti PF, Bombieri C, Marigo C, Benetazzo M, Luisetti M. Increased incidence of cystic fibrosis gene mutations in adults with disseminated bronchiectasis. Hum Mol Genet 1995;4:635-9.

7 Pignatti PF, Bombieri C, Benetazzo M, Casartelli A, Trabetti E, Gile LS, Martinati LC, Boner AL, Luisetti M. CFTR gene variant IVS-5T in disseminated bronchiectasis. Am f Hum Genet 1996;58:889-92.

8 Patrizio P, Zielenski J. Congenital absence of the vas deferens: a mild form of cystic fibrosis. Mol Med Today 1996;2:24-31.

9 Lázaro C, de Cid R, Sunyer J, Soriano J, Gimenez J, Alvarez M, Casals T, Anto JM, Estivill X. Missense mutations in the cystic fibrosis gene in adult patients with asthma. Hum Mutat 1999;14:510-19.

10 Girodon E, Cazeneuve C, Lebargy F, Chinet T, Costes B, Ghanem N, Martin J, Lemay S, Scheid P, Housset P, Bignon J, Goosens M. CFTR gene mutations in adults with disseminated bronchiectasis. Eur $\mathcal{F}$ Hum Genet 1997;5:149-55.

11 Cockrill BA, Hales CA. Allergic bronchopulmonary aspergillosis. Annu Rev Med 1999;50:303-16.

12 Irving RM, McMahon R, Clark R, Jones NS. Cystic fibrosis transmembrane conductance regulator gene mutations in severe nasal polyposis. Clin Otolaryngol 1997;22:519-21.

13 Sharer N, Schwarz M, Malone G, Haworth A, Painter J, Super M, Braganza J. Mutations of the cystic fibrosis gene in patients with chronic pancreatitis. N Engl f Med 1998;339:645-52.

14 Dörk T, Dworniczak B, Aulehla-Scholz C, Wieczarek D, Bohm I, Mayerova A, Seydewitz HH, Nieschlag E, Meschede D, Horst J, Pander HJ, Sperling H, Ratjen F, Passarge E, Schmidtke J, Stahrmann M. Distinct spectrum of $\mathrm{H}$, Ratjen F, Passarge E, Schmidtke J, Stahrmann M. Distinct spectrum of
CFTR gene mutations in congenital absence of vas deferens. Hum Genet CFTR gene muta

15 Hughes D, Wallace A, Taylor J, Tassabehji M, McMahon R, Hill A, Nevin $\mathrm{N}$, Graham C. Fluorescent multiplex microsatellites used to define haplotypes associated with 75 CFTR mutations from the UK on 437 CF chromosomes. Hum Mutat 1996;8:229-35.

16 Niksic M, Romano M, Buratti E, Pagani F, Baralle F. Functional analysis of cis-acting elements regulating the alternative splicing of human CFTR exon 9. Hum Mol Genet 1999;8:2339-49.

17 Roberts G, Stanfield M, Black A, Redmond AO. Screening for cystic fibrosis: a four year regional experience. Arch Dis Child 1988;63:1438-44.

18 Highsmith WE, Burch LH, Zhou Z, Olsen JC, Boat TE, Spock A, Gorvoy JD, Quittel L, Friedman KJ, Silverman LM. Cystic fibrosis gene mutation in patients with normal sweat chloride concentrations. N Engl f Med 1994; in patients

19 Hughes DJ, Hill AJ, Macek M Jr, Redmond AO, Nevin NC, Graham CA. Mutation characterization of the CFTR gene in 206 Northern Irish CF families: 30 mutations, two of which are novel, account for $94 \%$ of CF families: 30 mutations, two of which are
chromosomes. Hum Mutat 1996;8:340-7.

20 Chu CS, Trapnell BC, Murtagh JJ, Moss J, Dalemans W, Jallat S, Mercenier A, Pavirani A, Lecocq JP, Cutting GR. Variable deletion of exon 9 coding sequences in cystic fibrosis transmembrane conductance regulator gene mRNA transcripts in normal bronchial epithelium. EMBO f 1991;10: 1355-63.

21 Rave-Harel N, Kerem E, Nissim-Rafinia M, Madjar I, Goshen R, Augarten A, Rahat A, Hurwitz A, Darvasi A, Kerem B. The molecular basis of partial penetrance of splicing mutations in cystic fibrosis. Am f Hum Genet 1997; 60:87-94.

22 Chillon M, Casals T, Mercier B, Bassas L, Lissens W, Silber S, Romey MC, Ruiz-Romero J, Verlingue C, Claustres M. Mutations in the cystic fibrosis gene in patients with congenital absence of the vas deferens. N Engl f Med gene in patients with

23 Mak V, Jarvi KA, Zielenski J, Durie P, Tsui LC. Higher proportion of intact exon 9 CFTR mRNA in nasal epithelium compared with vas deferens. exon 9 CFTR mRNA in nasal epit
Hum Mol Genet 1997;6:2099-107.

24 Larriba S, Bassas L, Gimenez J, Ramos MD, Segura A, Nunes V, Estivill X, Casals T. Testicular CFTR splice variants in patients with congenital absence of the vas deferens. Hum Mol Genet 1998;7:1739-43.

25 de Meeus A, Guittard C, Desgeorges M, Carles S, Demaille J, Claustres M. Linkage disequilibrium between the M470V variant and the IVS poly $\mathrm{T}$ alleles of the CFTR gene in CBAVD. F Med Genet 1998;35:594-6.

26 Taylor CJ. Chronic pancreatitis and mutations of the cystic fibrosis gene. Gut 1999;44:8-9.

27 Weiner-Miller P, Hamosh A, Macek M Jr, Greenberger PA, MacLean J, Walden SM, Slavin RG, Cutting GR. Cystic fibrosis transmembrane conductance regulator (CFTR) gene mutations in allergic bronchopulmonary aspergillosis. Am f Hum Genet 1996;59:45-51.

28 Kiesewetter S, Macek M Jr, Davis C, Curristin SM, Chu CS, Graham C Shrimpton AE, Cashman SM, Tsui LC, Mickle J, Amos J, Highsmith WE, Shuber A, Witt DR, Crystal RG, Cutting GR. A mutation in CFTR produces different phenotypes depending on chromosomal background. produces different phenoty

29 Oates R, Amos J. Congenital bilateral absence of the vas deferens. A genetic commonality. World f Urol 1993;11:82-8.

30 Zielenski J, Tsui LC. Cystic fibrosis: genotypic and phenotypic variations. Annu Rev Genet 1995;29:777-807.

31 Graham CA, Goon PKC, Hill AJM, Cutting GR, Curristin S, Nevin NC. Identification of a new mutation (R297Q) in exon 7 of the CFTR gene in a Northern Ireland family. $\mathcal{F}$ Med Genet 1991;28:571

32 Dorval I, Jézéquel P, Chauvel B, Dubourg C, Fergelot P, Le Gull JY, Roussey $M$, Blayau $M$. French CF family genotype analysis shows that the R297Q mutation is a rare polymorphism. Hum Mutat 1995;6:334-5.

33 Tebbutt SJ, Harris A, Hill DF. An ovine CFTR variant as a putative cystic fibrosis causing mutation. $\mathcal{F}$ Med Genet 1996;33:623-4.

34 Hughes D, Hill A, Redmond A, Nevin N, Graham C. Fluorescent multiplex microsatellites used to identify haplotype associations with 15 CFTR mutations in 124 Northern Irish CF families. Hum Genet 1995;95:462-4 
35 Mekus F, Ballmann M, Bronsveld I, Dörk T, Bijman J, Tümmler B, Veeze HJ. Cystic-fibrosis-like disease unrelated to the cystic fibrosis transmemHJ. Cystic-fibrosis-like disease unrelated to the cystic fibrosi
brane conductance regulator. Hum Genet 1998;102:582-6.
36 Dörk T, Fislage R, Neumann T, Wulf B, Tümmler B. Exon 9 of the CFTR gene: splice site haplotypes and cystic fibrosis mutations. Hum Genet 1994; gene: splice

\section{Risk perception and cancer worry: an exploratory study of the impact of genetic risk counselling in women with a family history of breast cancer}

EDITOR-An important aim of genetic risk counselling is to confirm a level of cancer risk and offer risk management strategies. ${ }^{1}$ By giving counsellees accurate information about their risk, in place of ignorance, uncertainty, or a false assumption of the inevitability of breast cancer, it is hoped that some of the associated worry about personal risk may be alleviated.

Earlier work by the authors showed that women frequently overestimate their risk of breast cancer, ${ }^{2}$ creating the possibility of reassuring women by providing a more realistic risk value. Subsequent research showed that risk counselling significantly improved risk accuracy over a one year follow up period, both for women who overestimated and underestimated risk. ${ }^{3}$ This improvement was more likely if women were sent a personal letter containing the risk information after their visit. ${ }^{3}$ However, there was concern that accurate risk information may induce or increase anxiety in women referred for genetic counselling, especially in those who initially underestimated their risk.

This was not borne out by a study of first time attendees at the Family History Clinic, who were followed for a one year period after genetic risk counselling. Women were found to adopt a more accurate perception of their risk without an increase in scores on general measures of anxiety at any time point post-counselling. ${ }^{4}$ There was a suggestion from questionnaire data that women with an accurate appraisal of risk after genetic counselling had the best levels of mental health and psychiatric diagnoses derived by interview were not caused by risk counselling. However, some women with psychiatric morbidity reported that the early loss of a mother was very difficult to resolve, ${ }^{4}$ a problem also reported in adolescent daughters of breast cancer patients. ${ }^{5}$ The relationship between early loss and cancer worry in high risk women has not been previously reported. Death of a mother in adolescence may be associated with a greater fear of cancer as an adult, because of exposure to the disease at this vulnerable age. Adolescent daughters of women with breast cancer find it difficult to put the illness behind them and report higher symptom scores for distress. ${ }^{5}$

Our previous study showed that genetic risk counselling did not adversely effect mental health, but the study lacked a specific measure of cancer worry. A previous UK study reported that specific cancer worry was not relieved by genetic risk counselling. ${ }^{6}$ Perceived risk was the best predictor of cancer worry and intuitively one would expect women who overestimate to have more cancer worries but be amenable to reassurance from accurate risk knowledge. Thus, we considered it important to assess cancer worry prospectively and longitudinally in women at risk and, secondly, to find out whether the early loss of a mother had a bearing on the level of cancer worry.
It was hypothesised that (1) cancer worry scores would be greater in women who overestimated risk than in those who underestimated or had an accurate risk perception; (2) cancer worries would be greater in women whose mothers died from breast cancer before the daughters were aged 20, with those aged 10 to 20 (that is, adolescents) at the time of death being the most vulnerable; and (3) cancer worry scores would show no significant change following risk counselling.

At the time of study, the Family History Clinic service offered risk assessment to women with a family history of breast/ovarian cancer who had a minimum two-fold increased risk compared with the general population, but who were unaffected. The service was staffed by a consultant cancer geneticist, a consultant medical oncologist with expertise in risk assessment, and a Research Fellow in cancer genetics. Earlier research showed that women's risk perceptions post-counselling did not vary according to which clinician had provided risk counselling. ${ }^{4}$ Referrals were received from general practitioners $(>70 \%)$ and from surgeons/other clinicians but women could not self-refer. A detailed pedigree was first obtained by a mailed questionnaire which was then computed and risk level estimated using the Claus model. ${ }^{7}$ Women reaching criterion risk were offered an appointment at which the family history was discussed and a personal risk level presented. Risk was given in two ways, including an odds ratio for lifetime risk. Clinical breast examination and mammography (where appropriate) were also provided. All women were sent a detailed letter after the consultation, summarising the discussion and including the lifetime risk value. Very few women attending the service would be able to consider genetic testing because many were not from obviously "dominant" breast cancer families, which is where most testing is focused.

An assessment of pre-counselling risk perception and cancer worry has formed part of the routine work up for new referrals to the Manchester Family History Clinic in recent years. The study population was formed by 500 newly referred women offered an appointment at the clinic, who had completed Lerman's Cancer Worry Scale $(\mathrm{CWS})^{89}$ and the Manchester Family History Clinic Questionnaire $^{4}$ (to assess risk perception) before their first attendance at the Family History Clinic.

A second pair of questionnaires was posted to 460 of these women in July 1998, a minimum of two and maximum of 21 months after genetic risk counselling with a letter requesting completion. Forty women who had already been approached to participate in another research study running concurrently were not recontacted. (These women were participating in the Tamoxifen Chemoprevention Trial, IBIS.) The CWS is a six item (originally four item) scale designed to measure worry about the risk of developing cancer and the impact of worry on daily functioning. Reference population norms are available, ${ }^{8}$ but no clinical case threshold values are derived.The Family History Clinic Questionnaire provides information on source of referral, reason for attending, risk perception, and concern about risk. It has been used in several previous research studies ${ }^{2-4}$ and showed consistency over time. Risk perception is assessed through selection of the appropriate 